\title{
Curling of Hair in Two Female Patients Taking Alitretinoin
}

\author{
Kim Alting ${ }^{1}\left[\right.$. Florence van Hunsel ${ }^{1}$
}

Published online: 16 October 2018

(c) The Author(s) 2018

\begin{abstract}
Two female patients aged 45 and 51 years experienced curling of hair during treatment with alitretinoin (Toctino ${ }^{\circledR}$ ). For one patient, the indication for use was severe chronic hand eczema, but for the second patient the indication was not reported. After 5 and 9 months, respectively, the patients developed hair texture changes and their straight hair began to curl. The dose of alitretinoin was reduced in both cases, but the patients' hair had not straightened at the time of reporting ( 9 months and 2 years after onset of the event). Based on the described reports received by the Netherlands Pharmacovigilance Centre Lareb, the case reports in the literature, and the possible mechanisms, we suggest a causal relationship between curling of the hair and the use of alitretinoin. Using the World Health Organization Uppsala Monitoring Centre (WHO-UMC) system for standardized case causality assessment, the association in our cases can be assessed as likely.
\end{abstract}

\section{Key Points}

Drugs may cause various changes in hair, such as hair loss, stimulating hair growth, or inducing changes in hair shape and color.

Curling of the hair has been described, and is labelled for some systemic retinoids such as isotretinoin and acitretin, but is not a labelled adverse drug reaction for alitretinoin.

\section{Introduction}

Alitretinoin is a vitamin A derivative that belongs to the systemic retinoids class and is indicated for use in adults who have severe chronic hand eczema that is unresponsive to treatment with potent topical corticosteroids. The duration of treatment (30 mg once daily or $10 \mathrm{mg}$ when experiencing adverse drug reactions [ADRs]) is usually 12-24 weeks, depending on the patient's response. Alopecia is a known ADR for this drug. Changes in hair texture, such as curling

Kim Alting

k.alting@lareb.nl

1 Netherlands Pharmacovigilance Centre Lareb, 's-Hertogenbosch, Goudsbloemvallei 7, 5237 MH's Hertogenbosch, The Netherlands or brittleness of the hair, are not described in the Summary of Product Characteristics (SmPC) for this drug [1, 2], but are mentioned in SmPCs of other systemic retinoids, such as isotretinoin and acitretin [3, 4]. A few cases have also been reported in the literature in which retinoids such as isotretinoin, acitretin and etretinate have been attributed to changes in hair texture or color $[9,12,13,15-21]$. Changes in hair texture may potentially affect compliance, thereby resulting in less efficacy of therapy. In the period from January 2016 to September 2017, The Netherlands Pharmacovigilance Centre Lareb (Lareb) received two reports from female patients describing that their straight hair became curly after using alitretinoin.

\section{Case Reports}

\section{Patient A}

In January 2016, a 51-year-old woman reported to Lareb that her straight hair became curly after the use of alitretinoin (unspecified dose; Toctino $^{\circledR}$ ) for 9 months (Fig. 1). The indication of use was not reported. The patient mentioned her hair started curling gradually and was becoming more and more difficult to style in the desired fashion. Her hair was not thinning or brittle and the patient mentioned there were no other problems with her hair or scalp. The patient talked to her specialist about the ADR and the dose for alitretinoin was reduced to $10 \mathrm{mg}$. At the time of follow-up, 2 years 


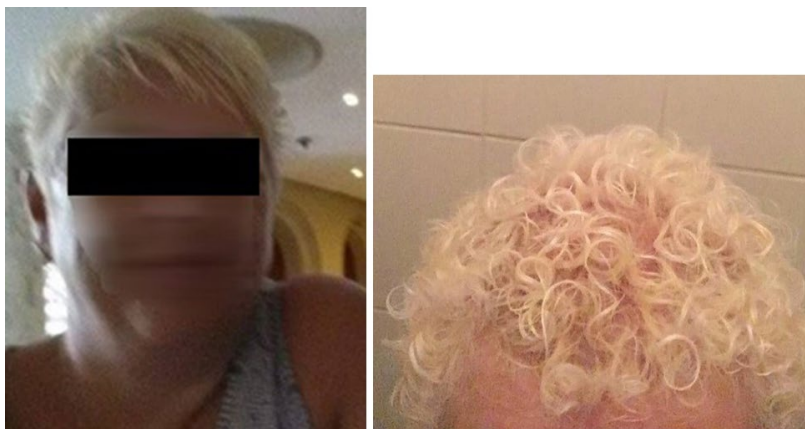

Fig. 1 Hair texture changes from straight (left) to curly (right)
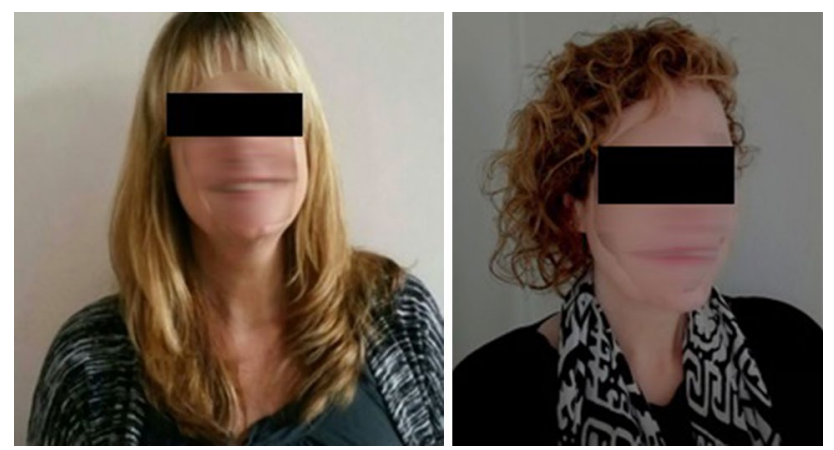

Fig. 2 Hair texture changes from straight (left) to curly (right). The patient did not use any hair styling products in the photos

after onset of the event, the patient's hair still had a different texture while using this lower dose and did not straighten. The patient mentioned that when keeping her hair short, the curling was less than when her hair grew longer. The patient was taking tramadol as concomitant medication, for which hair texture changes are not a known ADR. It is not known whether the patient had other medical conditions that could have led to the curling of her hair.

\section{Patient B}

In January 2017, a 45-year-old woman reported to Lareb that she suffered from diffuse alopecia and her straight hair became curly following administration of alitretinoin $\left(\right.$ Toctino $\left.^{\circledR}\right) 30 \mathrm{mg}$ for hand eczema with a latency of 5 months (Fig. 2). The patient mentioned her hair started changing and falling out after approximately 6 months. The ADR was discussed with the patient's dermatologist, who noted the change in hair texture. The use of alitretinoin was not discontinued, but the dose was reduced to $20 \mathrm{mg}$ due to a good therapeutic response. The patient mentioned that her hair had not straightened at the time of reporting, 9 months after onset of the events. It is unknown if the patient suffered from other medical conditions or used other drugs that could have played a part in the curling of her hair.

\section{Discussion}

Drugs may cause various changes in hair, such as hair loss, stimulating hair growth, or inducing changes in hair shape and color. Although alopecia is described for many drugs, a change in hair texture causing the hair to curl or kink is less common [14]. Although the hair of both patients had a curly appearance, there is a difference between kinked hair and curly hair. With kinking of the hair, the hair looks curly due to torsion and irregularities in hair structure. Curling of the hair is the result of an oval hair shaft, which grows out of the scalp under an angle. The amount of disulfide bonds between the hair proteins and hair shaft give rise to a certain degree of curling of the hair. Hair thinning can cause kinking of the hair; however, why this happens is unknown since factors determining different hair shapes are not completely understood. Factors that may be implicated include changes in the shape of the hair follicle during miniaturization, irregularities of mitosis within the hair bulb, and changes in the arrangement of the keratin filaments within the hair shaft [5].

The inner root sheath (IRS) is an important structure of the lower part of the hair follicle that surrounds and protects the growing hair, and is essential for the proper molding, adherence, and keratinization of the growing hair [7]. With regard to retinoids, an influence on the keratinization of the IRS of the hair follicle during the anagenic growth phase has been proposed as a possible mechanism. Given the chemical relationship of alitretinoin with the other retinoids and their effect on the retinoid acid receptors (RARS $\alpha, \beta, \gamma$ ), a similar mechanism can be expected. However, since retinoids also activate the thyroid- and vitamin $\mathrm{D}$ receptor-modulating retinoid X receptors (RXRS a, $\beta, \gamma$ ), alternative mechanisms are also possible [6]. These RXR receptors are speculated to play a role in new hair growth [9]. Etretinate may cause accelerated hair growth, dose-dependent telogen effluvium, and, at a high dose, hair loss that may be associated with dystrophy of hair roots [8]. It is speculative whether the affected hairs have regrown in follicles from which hairs have previously been lost. The keratinization of the IRS could be the result of a dystrophic change of the hair root. A similar process is seen in acquired pili-torti, when distortion of the hair follicle results in twisting of the hairs [10].

The question has risen whether there is an association between hair loss and acquired kinking of the hair, which resembles acquired progressive kinking of the hair $(\mathrm{APKH})$, a relatively rare condition, where hair kinking affects the frontotemporal regions of the head and the kinking is accompanied by a change in pigmentation of 
Table 1 Overview of case reports on other systemic retinoids [8, 11, 12, 14-20]

\begin{tabular}{|c|c|c|c|c|c|}
\hline Drug & $\begin{array}{l}\text { Reference (year of publi- } \\
\text { cation) }\end{array}$ & $\begin{array}{l}\text { Patient sex and age } \\
\text { (years) }\end{array}$ & Latency & Outcome & Other information \\
\hline \multirow[t]{8}{*}{ Etretinate $^{\mathrm{a}}$} & \multirow[t]{3}{*}{$\begin{array}{l}\text { Graham et al. [10] } \\
\text { (1985) }\end{array}$} & Male, 29 & 6 months & $\begin{array}{l}\text { Dose reduced, recover- } \\
\text { ing }\end{array}$ & $\begin{array}{l}\text { Also diffuse alopecia and } \\
\text { increased hair fragility }\end{array}$ \\
\hline & & Female, 62 & 6 months & Dose reduced, recovered & \\
\hline & & Male, 46 & 2 months & $\begin{array}{l}\text { Dose reduced, recover- } \\
\text { ing }\end{array}$ & Also diffuse alopecia \\
\hline & \multirow[t]{3}{*}{ Archer et al. [20] (1985) } & Female, 45 & Duration 15 months & Unknown & \\
\hline & & Female, 45 & Duration 12 months & Unknown & \\
\hline & & Male, 45 & Duration 10 months & Unknown & \\
\hline & \multirow{2}{*}{$\begin{array}{l}\text { Schauder et al. [22] } \\
\text { (1992) }\end{array}$} & Female & Unknown & Unknown & \\
\hline & & Female & Unknown & Unknown & \\
\hline \multirow[t]{3}{*}{ Acitretin } & Clarke et al. [13] (2007) & Female & 6 months & $\begin{array}{l}\text { Dose reduced, not } \\
\text { recovered }\end{array}$ & \\
\hline & $\begin{array}{l}\text { Seckin and Yildiz [14] } \\
\text { (2009) }\end{array}$ & Female, 70 & 6 months & $\begin{array}{l}\text { Dose not changed, out- } \\
\text { come unknown }\end{array}$ & $\begin{array}{l}\text { Also repigmentation } \\
\text { (from grey to black } \\
\text { hair) }\end{array}$ \\
\hline & Ward et al. [16] (2014) & Male, 61 & 1 year & $\begin{array}{l}\text { Dose not changed, out- } \\
\text { come unknown }\end{array}$ & $\begin{array}{l}\text { Thinning at first, repig- } \\
\text { mentation (from white } \\
\text { to darker grey) and } \\
\text { thicker hair after } 1 \text { year }\end{array}$ \\
\hline \multirow[t]{5}{*}{ Isotretinoin } & Bunker et al. [17] (1990) & Female, 46 & During a 1 -year period & $\begin{array}{l}\text { Withdrawal, recovered } \\
\text { within } 6 \text { months }\end{array}$ & \\
\hline & $\begin{array}{l}\text { Hays and Camisa [18] } \\
\text { (1985) }\end{array}$ & $\begin{array}{l}2 \text { females (mother and } \\
\text { daughter) }\end{array}$ & Unknown & Unknown & Pili-torti \\
\hline & \multirow{3}{*}{$\begin{array}{l}\text { Van der Pijl et al. [19] } \\
\text { (1996) }\end{array}$} & Male, 49 & 2 months & Unknown & Also azathioprine use \\
\hline & & Male, 46 & 60 days & Unknown & Also azathioprine use \\
\hline & & Unknown & 3 months & Unknown & Also azathioprine use \\
\hline \multirow[t]{2}{*}{ Alitretinoin } & Herink et al. [6] (2015) & Male, 44 & 4 months & Not changed, unknown & \\
\hline & $\begin{array}{l}\text { Trehan and Wilson [12] } \\
\text { (2016) }\end{array}$ & Female, 70 & 3 months & $\begin{array}{l}\text { Withdrawal, not recov- } \\
\text { ered }\end{array}$ & \\
\hline
\end{tabular}

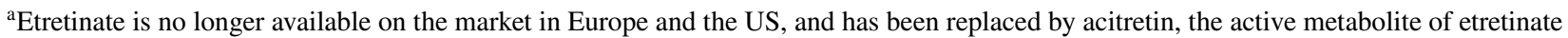

the hair $[6,20]$. Pigmentation of the hair is also regulated in the hair follicles. Judging from the photos in our cases, the hair color of the patients has changed. However, one patient explicitly mentioned her hairdresser noticed the hair texture change, therefore it is possible the patient used hair dye, which explains the difference in hair color.

Another possible cause for curling of the hair is hypothyroidism. Hypothyroidism is a medical condition that can lead to dry, thinning and coarse hair due to a hormonal disbalance [11]. Hair follicles are direct targets of thyroid hormones. T3 and/or T4 modulate multiple hair biology parameters and prolong the anagen phase duration, stimulate hair follicle pigmentation, and inhibit apoptosis of hair matrix keratinocytes, while T4 stimulates hair matrix keratinocyte proliferation. Both $\mathrm{T} 3$ and $\mathrm{T} 4$ do not seem to alter hair shaft formation in vitro [23]. However, this does not explain curling of the hair in our cases since the patients had no symptoms indicating hypothyroidism.
Several case reports were published regarding kinking of the hair in association with the systemic retinoids acitretin $[13,14,16]$, isotretinoin [17-19], and etretinate [10, 18, 20-22]. A short overview of these case reports is depicted in Table 1.

In addition, two previous cases relating to a 70-yearold woman and a 44-year-old man describe curling of the hair in association with alitretinoin $[6,12]$. The latency in these cases is 3 and 4 months after the start of alitretinoin. The 70-year-old woman withdrew alitretinoin, but 1 year after onset of the event the hair had not straightened [12]. From the case report of the 44-year-old man, it is unknown whether the hair had straightened. The dose for alitretinoin was not changed due to a good therapeutic effect [6]. Both cases were illustrated with photos of the hair texture changes.

By using clinical judgement and taking into account supporting photos and latency, the Lareb cases indicate a 
probable causal relationship between the use of alitretinoin and curling of the hair. Using the WHO-UMC system for standardized case causality assessment, the association in our cases can be assessed as likely [24].

\section{Conclusion}

Based on the described reports received by Lareb, the case reports in the literature, and the possible mechanisms, we suggest a causal relationship between curling of the hair and the use of alitretinoin. In addition, the change in hair texture after the use of retinoids might not be (quickly) reversible, depending on whether the hair shaft has been permanently damaged or not. Prescribers of alitretinoin and other retinoids should be aware of the possible effect of these drugs on hair texture so that they can inform their patients accordingly. In the cases reported to Lareb, both patients decided to continue their therapy despite their change in appearance, albeit in lower doses.

\section{Compliance with Ethical Standards}

Conflicts of Interest Kim Alting and Florence van Hunsel declare that they have no conflicts of interest/competing interests.

Funding No financial support was received for the conduct of this study or preparation of this manuscript.

Informed Consent Written informed consent was obtained from each of the patients for the publication of these case reports and for inclusion of the accompanying images. Copies of the consents may be requested for review from the corresponding author.

Open Access This article is distributed under the terms of the Creative Commons Attribution-NonCommercial 4.0 International License (http://creativecommons.org/licenses/by-nc/4.0/), which permits any noncommercial use, distribution, and reproduction in any medium, provided you give appropriate credit to the original author(s) and the source, provide a link to the Creative Commons license, and indicate if changes were made.

\section{References}

1. Dutch SmPC Toctino ${ }^{\circledR} 10 \mathrm{mg}$ capsules (version date: $18-7-2017$ ) [in Dutch]. Available at: https://db.cbg-meb.n1/IB-teksten/h1009 57.pdf. Accessed 4 Jun 2018.

2. UK SPC Toctino $10 \mathrm{mg}$ and $30 \mathrm{mg}$ capsules (version date: $15-8$ 2017). Available at: https://www.medicines.org.uk/emc/medic ine/21177/SPC/Toctino+10mg+and+30mg+soft+capsules/. Accessed 16 Jun 2018.

3. Dutch SmPC Isotretinoïne $10 \mathrm{mg}$ capsules (version date: 25-112016) [in Dutch]. Available at: https://db.cbg-meb.nl/IB-teksten/ h26547.pdf. Accessed 4 Jun 2018.
4. Dutch SmPC Acitretine (Neotigason $\left.{ }^{\circledR}\right) 10 \mathrm{mg}$ capsules (version date: 11-10-2016). Available at: https://db.cbg-meb.nl/IB-teksten/ h13103.pdf. Accessed 4 Jun 2018.

5. Tosti A, Piraccini BM, Pazzaglia M. Acquired progressive kinking of the hair-clinical features, pathological study, and follow-up of 7 patients. Arch Dermatol. 1999;135(10):1223-6.

6. Herink C, Schön MP, Mößner R. Development of curly hair under systemic therapy with alitretinoin. Hautarzt. 2015;66(8):617-9.

7. Joshi RS. The inner root sheath and the men associated with it eponymically. Int J Trhichology. 2011;3(1):57-62.

8. Mahrle G, Orfanos CE, Ippen H, Hofbauer M. Haarwachstum, leberwerte und lichtempfindlichkeit unter oraler retinoid-therapie bei psoriasis. Deutsche Medizinishe Wochenschrift. 1979;104:473-7.

9. Kolesnik M, Gollnick H, Bonnekoh B. Complete remission of alopecia areata under treatment of chronic hand eczema with alitretinoin. Eur J Dermatol. 2013;23(1):110-1.

10. Graham RM, James MP, Ferguson DJ, Guerrier CW. Acquired kinking of the hair associated with etretinate therapy. Clin Exp Dermatol. 1985;10(5):426-31.

11. Up-To-Date. Clinical manifestations of hypothyroidism. Available at: https://www.uptodate.com/contents/clinical-manifestations-ofhypothyroidism?search=hypothyroidism\&source=search_resul t\&selectedTitle $=3 \sim 150 \&$ usage_type $=$ default\&display_rank $=3$. Accessed 14 Jun 2018.

12. Trehan P, Wilson NJ. Alitretinoin-induced curling of the hair. Australas J Dermatol. 2016;57(2):155.

13. Clarke JT, Price H, Clarke S, George R, Miller JJ. Acquired kinking of the hair caused by acitretin. J Drugs Dermatol. 2007;6(9):937-8.

14. Seckin D, Yildiz A. Repigmentation and curling of hair after acitretin therapy. Australas J Dermatol. 2009;50(3):214-6.

15. Tosti A, Pazzaglia M. Drug reactions affecting hair: diagnosis. Dermatol Clin. 2007;252(2):223-31.

16. Ward PD, Miller HL, Shipman AR. A case of repigmentation and curling of hair on acitretin therapy. Clin Exp Dermatol. 2014;39(1):91-2.

17. Bunker CB, Maurice PD, Dowd PM. Isotretinoin and curly hair. Clin Exp Dermatol. 1990;15(2):143-5.

18. Hays SB, Camisa C. Acquired pili torti in two patients treated with synthetic retinoids. Cutis. 1985;35(5):466-8.

19. Van der Pijl JW, Bavinck JN, de Fijter JW. Isotretinoin and azathioprine: a synergy that makes hair curl? Lancet. 1996;348(9027):622-3.

20. Archer CB, Cerio R, Griffiths WAD. Etretinate and acquired kinking of the hair. Clin Exp Dermatol. 1987;12:239.

21. Mortimer PS. Unruly hair. Br J Dermatol. 1985;113(4):467-73.

22. Schauder S, Tsambaos D, Nikiforidis G. Curling and kinking of hair caused by etretinate. Hautarzt. 1992;42(8):509-13.

23. Van Beek N, Bodó E, Kromminga A. Thyroid hormones directly alter human hair follicle functions: anagen prolongation and stimulation of both hair matrix keratinocyte proliferation and hair pigmentation. J Clin Endocrinol Metab. 2008;93(11):4381-8.

24. World Health Organisation - the Uppsala Monitoring Centre. The use of the WHO-UMC system for standardized case causality assessment. Available at: http://www.who.int/medicines/areas/ quality_safety/safety_efficacy/WHOcausality_assessment.pdf. Accessed 21 Jun 2018. 